\title{
Trophic CASCADES AND BIODIVERSITY in Grand Teton NATIONAL PARK
}

\author{
DIANE DEBINSKI \\ ECOLOGY, EVOLUTION, AND ORGANISMAL BIOLOGY \\ IOWA STATE UNIVERSITY $\downarrow$ AMES
}

\begin{abstract}
$\downarrow$ AbSTRACT
The reintroduction of wolves into Grand Teton National Park has the potential of affecting species distribution patterns from the large ungulates down to the insect and plant communities. Trophic cascades, as these effects are called, epitomize the interconnectedness of ecological communities. My research team has been studying montane meadow biodiversity of plants, birds, and butterflies in the Grand Teton National Park since 1996. We have used satellite imagery to classify meadows along a moisture gradient into six categories (M1-M6). Hydric meadows are dominated by willows and sedges, mesic meadows have a diversity of grasses and flowering plants, and xeric meadows are dominated by sagebrush and grasses. These meadows are important reservoirs of biodiversity in the arid Rocky Mountain ecosystems. We have identified a suite of species in each taxonomic group that are tightly linked with each of the meadow types. We expect that as wolves move into Grand Teton National Park and the surrounding areas, there will be changes in herbivory and species distribution patterns that will cascade through the system. This research will focus on monitoring montane meadow communities to test for trophic cascades in the willow and bird communities.
\end{abstract}

\section{$\uparrow \quad$ INTRODUCTION}

The first pack of wolves arrived in Grand Teton National Park in 1999. We expect the population to expand significantly as wolves breed in
Grand Teton National Park and disperse south from Yellowstone National Park. In Yellowstone National Park's northern winter range, height release of willows and cottonwoods has allowed them to grow beyond the reach of large ungulates (Beschta 2003; Ripple and Beschta 2003; Singer et al. 2003). Wolves have the potential to affect the distribution and abundance of herbivores in Grand Teton National Park both directly (through predation) and indirectly (through behavioral modification). By reducing the numerical abundance of a competitively dominant prey species (or by changing its behavior), carnivores erect and enforce ecological boundaries that allow weaker competitors to persist. As a result, a new suite of prey species abundances (e.g., herbivores) may result. Because herbivores eat seeds and plants, predation on herbivores influences the structure of the plant community. The plant community, in turn, influences distribution, abundance, and competitive interactions within groups of birds, mammals, and insects. Thus, the impact of carnivores extends past the objects of their predation, and the reintroduction of wolves into Grand Teton National Park has the potential of affecting species distribution patterns from the large ungulates down to the insect and plant communities. Trophic cascades, as these effects are called, epitomize the interconnectedness of ecological communities.

My research team has been studying montane meadow biodiversity of plants, birds, and butterflies in the Greater Yellowstone Ecosystem since 1996. This new dimension of research will focus on sites in Grand Teton National Park and Bridger Teton National Forest. We have 
used satellite imagery to classify meadows along a moisture gradient into six categories (M1-M6) ranging from hydric (M1) to mesic (M3) to xeric (M6). Hydric meadows are dominated by willows and sedges, mesic meadows have a diversity of grasses and flowering plants, and xeric meadows are dominated by sagebrush and grasses. These meadows are important reservoirs of biodiversity in the arid Rocky Mountain ecosystems. Because montane meadows are dominated by grasses, forbs and shrubs, and because they are significantly affected by herbivory, they have the potential to exhibit changes much more quickly than forested ecosystems in the presence of wolves.

Birds are an excellent taxon to examine as indicators of trophic cascades because they are speciouse (over 100 species are present in the ecosystem). Birds respond directly to vegetation structure. Thus, birds have the ability to measure the combined effects of herbivory changes from the perspective of both composition and structure. Berger et al. (2001) have also examined the effects of trophic cascades on birds in Grand Teton National Park and found that reduced grazing on herbaceous vegetation and reduced browsing of willows resulted in increased abundance and diversity of avifauna. The total number of bird species (species richness) increased $28 \%$ and the total bird density increased in willow communities with $80 \%$ fewer moose $/ \mathrm{km}^{2}$ in the Jackson Valley (Berger et al. 2001). Obligate riparian birds (e.g., gray catbirds and MacGillivray's warblers), disappeared in the most heavily-browsed willow patches, whereas open meadow bird species (e.g., meadowlarks) increased.

Through our previous work we have identified the species of birds that show direct affinities to specific meadow types. We have also documented how the structure of willow communities can have significant effects on songbird distribution and abundance. We expect that many of the differences we have observed in abundance of the hydric-related species (e.g., Common Snipe, Common Yellowthroat, Lincoln's Sparrow, and Yellow Warbler) between the Gallatin and Teton region (Table 1) may be explained by willow height. We expect that the hydric to mesic meadows, which support willow, aspen, forbs and grasses will show the most dramatic changes but we are also interested in examining potential effects in the dryer sagebrush habitats.

Four years ago, I began a collaborative research project with Drs. Brian Miller and Hank Harlow who are studying the distribution of wolves, mesopredators, and small mammals in montane meadows. They began their mammal surveys using the Debinski et al. (1999) montane meadow classification within some of our sampling sites and in 1999 they added comparable sites of each of the three major meadow types (M1, M3 and M6) within the territory of the wolves. This work continues the collection of our long-term ecological data in collaboration with Drs. Miller and Harlow to document changes in ecological communities associated with the movement of wolves into the ecosystem.

As ecologists study the reintroduction of this large carnivore, it is important to understand the effects of its presence from a variety of perspectives. Very few long-term data sets exist which will allow ecologists to document fine-scale changes in species distribution over time. Even fewer data sets exist which link data collected for multiple taxonomic groups across the same sites. Here we have an excellent opportunity to examine the composition of an ecological community before and after the reintroduction of wolves.

Without long-term site-specific data, it will be virtually impossible to determine whether the reintroduction of wolves is having direct effects on ecological communities. Fine-scale shifts of species distribution patterns might remain undocumented until a threshold is reached and large-scale changes have occurred. We believe that the bird community can serve as an important indicator of environmental change and that our data will provide important documentation of the responses of the ecological community to wolf reintroduction.

\section{$\downarrow \quad$ OBJECTIVES AND HYPOTHESES}

The overall objective of this research is to document the effects of wolves throughout the ecological community across a broad range of taxonomic groups. The central hypothesis is that the presence of wolves in the ecosystem will create a trophic cascade of effects changing the structure and composition of montane meadow communities. Although bears have been present throughout our sampling time, the presence of a new major predator should have dramatic effects on the ecosystem. We are in a position to measure these effects as the first pack of wolves recently set up residence in Grand Teton National Park. My research group has 7 years of data on biodiversity in montane meadows of Grand Teton National Park prior to the arrival of wolves. These data are the perfect baseline data sets 
to use in comparison to effects manifested after wolves arrive.

\begin{tabular}{|c|c|c|c|c|}
\hline \multirow[t]{2}{*}{ Species } & \multicolumn{2}{|l|}{1997} & \multicolumn{2}{|l|}{1998} \\
\hline & Gallatins & Tetons & Gallatins & Tetons \\
\hline American Robin & 14 & 18 & 19 & 10 \\
\hline Brewer's Blackbird & 14 & 16 & 7 & 18 \\
\hline Chipping Sparrow & 12 & 7 & 19 & 7 \\
\hline Common Snipe & 2 & 10 & 8 & 9 \\
\hline Common Yellowthroat & 3 & 29 & 5 & 24 \\
\hline Dark-eyed Junco & 11 & 2 & 19 & 3 \\
\hline Lincoln's Sparrow & 34 & 35 & 53 & 31 \\
\hline Savannah Sparrow & 10 & 26 & 10 & 17 \\
\hline Vesper Sparrow & 24 & 58 & 26 & 24 \\
\hline White-crowned Sparrow & 14 & 46 & 13 & 21 \\
\hline Yellow Warbler & 0 & 53 & 1 & 39 \\
\hline
\end{tabular}

Specific objectives of this research with the related working hypotheses are listed below:

Objective 1: Document changes in the structure and composition of willow communities (M1 hydric meadows) as wolves expand throughout the ecosystem.

H1: Willow habitats will increase in stature because of decreases in herbivore pressure.

H2: Songbird species associated with willows (Yellow Warblers, Wilson's Warblers, Common Yellowthroats, Willow Flycatchers, Song Sparrows, Lincoln's Sparrows, and Fox Sparrows) will increase in abundance and density as willows increase in stature.

Objective 2: Document changes in the composition of mesic meadow communities (M3 meadows) as wolves expand throughout the ecosystem.

H3: Mesic meadow bird communities will not change significantly in composition because most of the changes in herbivory will be manifested in the more hydric meadows.

Objective 3: Document changes in the composition of xeric meadow communities (M6 meadows) as wolves expand throughout the ecosystem.

H4: Xeric meadow bird communities will not change significantly in composition because most of the changes in herbivory will be manifested in the more hydric meadows.

\section{APPROACH}

\section{Habitat classification}

Landsat Thematic Mapper data were used to identify a moisture gradient in montane meadows of the Greater Yellowstone Ecosystem (Jakubauskas and Debinski, 1995). Six meadow types were defined, ranging from extremely hydric (M1) to extremely xeric (M6) meadows. Field investigations confirmed the moisture gradient predicted for the meadows (Debinski et al., 2000, Jakubauskas et al., 1998; Kindscher et al. 1998). M1 and M2 meadows are sedge (Carex spp.) marshes with some standing water. M3 and M4 meadows are characterized by medium moisture with cinquefoil (Potentilla spp.) and mixed herbaceous vegetation, while M5 meadows have a mixture of sagebrush (Artemesia tridentata) and herbaceous vegetation. M6 meadows are characteristically xeric, rocky, and dominated by sagebrush. Because there was not a high frequency of M4 habitat in the Teton region, we used only five habitats (M1-M3, M5-M6). We established five replicates of each meadow type for a total of 25 sampling sites in the Tetons. These sites have had plant, bird, and butterfly species data collected annually from 1997-2001. They have had biomass data collected in 1997-1999 and vegetation structure data collected in 2000 . The data collection methods outlined below are the same methods that have been used in the past. 


\section{Vegetation sampling techniques}

Vegetation structure (height and obscurity) data were measured using three $100 \mathrm{~m}$ transects at each M1 site. These transects were labeled "west," "center," and "east" and run north-south at a distance of $30 \mathrm{~m}$ from one another. The center transect ran through the center of the bird point count plot (see below). Five stops, placed $20 \mathrm{~m}$ apart, were made along each transect. At each stop the following data were collected: vegetation type (grass, forb, shrub, etc), the max height of each vegetation type, and the percent obscurity of the vegetation pole by that vegetation. The pole used for the percent obscurity measurements was partitioned into $10 \mathrm{~cm}$ segments up to $125 \mathrm{~cm}$. Each segment was considered a "zone" and the percent obscurity was estimated as follows: $0 \%$ $=0 ; 1-20 \%=1 ; 20-40 \%=20 ; 40-60 \%=40$; etc.

\section{Bird sampling}

Abundance data was collected for birds in each of the sampling sites twice per year. Birds were surveyed between $0530-1030$ hrs using point counts in $100 \mathrm{~m}$ diameter circular plots. Two observers were present for each $15 \mathrm{~min}$ survey. One point count was conducted at each site. Bird data were collected from early June to mid-July.

\section{$\uparrow \quad$ RESULTS}

Vegetation and bird survey data have been entered into a database and we are currently in the process of assessing long-term trends.

\section{SUMMARY}

The goal of this research is to continue monitoring of long-term, well-established biodiversity inventory \& monitoring sites in Grand Teton National Park in the context of analyzing effects of trophic cascades. We have previously identified bird species that are statistically correlated with spectrally-based meadow habitat types. We have developed models for predicting several of the most abundant bird species relative to meadow type (Saveraid et al., 2001). We have shown that low elevation mesic montane meadows (meadows in an intermediate portion along the moisture gradient) have the highest plant diversity and also the greatest seasonal and interannual variation in spectral signature (Debinski, et al, 2000). Very few research projects have the number of years of baseline data that we now have and very few projects have the diversity of taxonomic groups surveyed concurrently at the same sites. We strongly believe that these montane meadows will be excellent indicators of environmental change due to trophic cascades. Our research team has some excellent preliminary data, a broad level of expertise to bring to the project, and the research proposed herein can only become more important as we enter an era where wolves recolonize Grand Teton National Park.

\section{$\uparrow \quad$ ACKNOWLEDGEMENTS}

This research was supported by the UWNPS Research Station and the Denver Zoo Foundation. I would like to thank Brian Miller for his collaboration on this project and Pamela Albers, and Michael Strauser for assistance in the field.

\section{$\uparrow \quad$ Literature Cited}

Beschta, R. L. 2003. Cottonwoods, elk, and wolves in the Lamar Valley of Yellowstone National Park. Ecological Applications 13:1295-1309.

Berger, J., P. B. Stacey, L. Bellis, and M. P. Johnson. 2001. A mammalian predator-prey imbalance: grizzly bear and wolf extinction affect avian neotropical migrants. Ecological Applications 11:947-960.

Debinski, D.M., M.E. Jakubauskas, and K. Kindscher. 1999. A remote sensing and GIS-based model of habitats and biodiversity in the Greater Yellowstone Ecosystem. International Journal of Remote Sensing 20:3281-3292.

Debinski, D.M., M.E. Jakubauskas, and K. Kindscher. 2000. Montane meadows as indicators of environmental change. Environmental Monitoring and Assessment. 64:213-225.

Jakubauskas, M.E., and D.M. Debinski. 1995. An integrated spectral and ecological approach to mapping forest and meadow communities of the Greater Yellowstone Ecosystem. Abstracts, 1995 Association of American Geographers Annual Meeting, Chicago, Illinois. 
Jakubauskas, M.E., K. Kindscher, and D.M. Debinski. 1998. Multitemporal characterization and mapping of montane sagebrush communities using Indian IRS LISS-II imagery. Geocarto International 13:65-74.

Kindscher, K., A. Fraser, M.E. Jakubauskas, and D.M. Debinski. 1998. Identifying wetland meadows in Grand Teton National Park using remote sensing and average wetland values. Wetlands Ecology and Management 5:265-273.

Ripple, W. J., and R. L. Beschta. 2003. Wolf reintroduction, predation risk, and cottonwood recovery in Yellowstone National Park. Forest Ecology and Management 184:299-313.
Saveraid, E.H., D.M. Debinski, K. Kindscher, and M.E. Jakubauskas. (in press). A comparison of satellite data and landscape variables in predicting bird species occurrences in the Greater Yellowstone Ecosystem. Landscape Ecology 16(1):71-83.

Singer, F. J., G. Wang, and N. T. Hobbs. 2003. The role of ungulates and large predators on plants, community structure, and ecosystem processes in national parks. Chapter 13 in $\mathrm{C}$. J. Zabel and R. G. Anthony, editors. Mammal community dynamics: Management and conservation in the coniferous forests of western North America. Cambridge University Press. 732 pp. 